\title{
In vitro study of the effect of different ionophore antibiotics and of certain derivatives on rumen fermentation and on protein nitrogen degradation
}

\author{
M.-C. Hillaire ${ }^{1}$, J.P. Jouany ${ }^{1}$, C. Gaboyard ${ }^{2}$ and G. Jeminet ${ }^{2}$ \\ 1 Station de recherches sur la nutrition des herbivores, unité de la digestion microbienne, INRA, \\ Theix, 63122 Ceyrat, and \\ 2 Laboratoire de chimie organique biologique, UA 485 du CNRS, Université Blaise-Pascal \\ (Clermont-Ferrand), Les Cézeaux, 63170 Aubière, France
}

(received 26 August 1988, accepted 23 February 1989)

Summary - An in vitro study was carried out to evaluate the effect of different ionophore antibiotics and some of their derivatives on rumen fermentation and on the degradation of peanut meal nitrogen. The increase in the production of propionic acid at the expense of acetic acid, observed with lonomycin, nigericin, cationomycin and lysocellin, was identical to that noted with monensin. The decrease in methanogenesis observed in the presence of monensin was also found with cationomycin and lysocellin. With the exception of lysocellin, which greatly reduced protein degradation of peanut meal, and of nigericin, which had no effect on this parameter, the 2 other molecules presented the same action as monensin. The negative effect of monensin on microbial ammonia uptake was demonstrated with the same intensity in the presence of cationomycin; it was slightly higher with nigericin and particularly accentuated with lonomycin and lysocellin. Three ester derivatives of monensin (monensin acetate, monensin propionate and monensin butyrate) had a similar action to that of monensin on the orientation of rumen fermentations. The monensin isobutyrate derivative appeared to be more active than monensin and only weakly altered microbial ammonia uptake. The oxolonomycin and hydroxolonomycin derivatives behaved identically to lonomycin with respect to microbial metabolism and protein nitrogen degradation. Unlike the molecules from which they derive, the deacylated cationomycin and nigericic acid had no effect on the orientation of rumen fermentations. Of the compounds tested and presenting a potential 'growthpromoting action' at least comparable to that of monensin, and which demonstrated lower toxicity on mice, three molecules (oxolonomycin, lysocellin and cationomycin) appeared to present a zootechnical interest as feed additives for growing cattle.

ionophore(s) - rumen - fermentation — nitrogen — volatile fatty acid(s) - gas

Résumé - Etude in vitro de l'influence de différents antibiotiques ionophores et de certains dérivés sur les paramètres fermentaires du rumen et sur la dégradation de l'azote protéique. Une étude in vitro a été conduite afin de tester l'influence de différents antibiotiques ionophores et certains de leurs dérivés sur les paramètres fermentaires du rumen et la dégradation d'une source azotée protéique (tourteau d'arachide). L'augmentation de la production d'acide propionique au détriment de l'acide acétique observée avec la lonomycine, la nigéricine, la cationomycine et la 
lysocelline a été identique à celle due à la monensine. La réduction de la méthanogenèse notée en présence de la monensine a également été retrouvée avec la cationomycine et la lysocelline. A l'exception de la lysocelline qui a fortement diminué la dégradation des protéines du tourteau d'arachide et de la nigéricine qui n'a eu aucun effet sur ce paramètre, les molécules ont présenté une action de protection comparable à celle de la monensine. L'effet négatif de la monensine sur la quantité d'ammoniaque fixée par les bactéries apparaît également, et avec la même intensité, avec la cationomycine; il est légèrement supérieur avec la nigéricine, et particulièrement accentué avec la lonomycine et la lysocelline. Trois dérivés esters de la monensine (monensine acétate, monensine propionate, monensine butyrate) ont eu une action semblable à celle de la monensine sur l'orientation des fermentations dans le rumen. Le dérivé monensine isobutyrate semble plus actif que la monensine et n'a que faiblement affecté la quantité d'ammoniaque fixée par les bactéries. Les dérivés oxolonomycine et hydroxolonomycine ont eu un comportement identique à celui de la lonomycine à l'égard du métabolisme microbien et de la dégradation de l'azote protéique. Contrairement aux molécules dont ils sont issus, la cationomycine déacylée et l'acide nigéricique n'ont eu aucun effet sur l'orientation des fermentations dans le rumen. Parmi les composés testés, qui ont présenté une activité "promoteur de croissance" au moins comparable à celle de la monensine et dont la toxicité déterminée sur souris est moindre, trois molécules (oxolonomycine, lysocelline et cationomycine) seraient susceptibles de présenter un intérêt zootechnique chez les bovins en croissance.

ionophore(s) - rumen - fermentation - azote - acide(s) gras volatil(s) - gaz

\section{Introduction}

lonophore antibiotics were initially used for their anticoccidial activity in poultry. Their growth-promoting effect was demonstrated in 1975 (Raun, 1974) when one of them, monensin, was used as feed additive for ruminants. Various in vitro and in vivo studies have defined their action on the orientation of rumen microbial metabolism (Durand, 1982; Bergen and Bates, 1984; Schelling, 1984). The increase in propionate at the expense of acetate, combined with a reduction in methanogenesis, improves energy metabolism. In addition, limiting degradation of dietary proteins in the rumen ensures a higher intestinal supply of $\alpha$-amino feed nitrogen. However, ionophore antibiotics can have a negative effect on microbial protein flow in the intestine. This effect is generally clear when measured by in vitro tests, but it disappears or is smaller when measured on animals adapted to diets containing an ionophore feed additive. In total, the $\alpha$ - amino nitrogen is not really modified because of the opposite evolution of its two components: feed and microbial nitrogen. Therefore, ionophore addition could lower the $\alpha$-amino supply for animals fed on diets rich in non-protein nitrogen.

However, the development of these molecules was limited by their toxicity and by the absence of precise data on their behaviour in animal tissues. Monensin has been the cause of severe intoxication in some farms following overdosage in the feed or by lack of homogenization of the feed mixture (Wardrope et al., 1983). At present, only monensin is approved in France, whereas monensin and lasalocid are both commonly used in the United States as growth promoters in young cattle. The European Commission of Additives, whose regulations on toxicity are very strict, have yet to approve any new molecules. This was the situation when we started to test the effect of new ionophore antibiotic molecules on rumen fermentation parameters and on the 
degradation of a protein nitrogen source (peanut meal) in comparison with a reference molecule, monensin.

We modified the structure of the molecules in order to change their toxicity level and thus explain the mode of action of ionophore antibiotics. We were particularly interested in the effects these modifications might have on rumen fermentation parameters.

\section{Materials and Methods}

\section{lonophore antibiotics tested}

During this study, we evaluated 5 natural ionophore antibiotics and 14 derivatives of 4 of them (Table I). Each antibiotic was tested using $1 \mathrm{mg}$ per fermenter, which was equivalent to 66 $\mathrm{mg} / \mathrm{kg}$ of solid substrate added or $2.6 \mathrm{mg}$ per liter of liquid in fermenters.

\section{In vitro study method}

A 'batch'-type experimental apparatus described by Jouany and Thivend (1986) was used to determine the action of the different ionophore antibiotics on the main rumen fermentation parameters.

The inoculum was composed of a mixture of the fluid and solid contents of the rumen removed from 5 rumen-fistulated sheep. These animals were daily fed $800 \mathrm{~g}$ of dehydrated alfalfa, $200 \mathrm{~g}$ of chopped wheat straw, $150 \mathrm{~g}$ of ground and pelleted barley and $250 \mathrm{~g}$ of natural prairie hay, given in 2 meals.

The test started by introducing into each fermenter the following inoculum: $100 \mathrm{ml}$ of total rumen contents, $100 \mathrm{ml}$ of the fluid obtained by filtration trough a metallic sieve and $200 \mathrm{ml}$ of a buffer solution (artificial saliva)* previously maintained at $40^{\circ} \mathrm{C}$ and saturated in $\mathrm{CO}_{2}(\mathrm{pH}$ 6.9). For each fermenter, a supply of ammonium sulfate $(5 \mathrm{ml}$ of a $17.6 \% \mathrm{w} / \mathrm{v}$ solution) ensured the nitrogen $(187 \mathrm{mg})$ and sulfur $(212 \mathrm{mg})$ needs of the microorganisms. The energy source was supplied either by wheat starch (control fermenters) or by wheat starch added to peanut meal providing $125 \mathrm{mg}$ of nitrogen (experimental fermenters). Eight fermenters were simultaneously incubated for a period of $6 \mathrm{~h}: 1-2$ (control): inoculum + $\left(\mathrm{NH}_{4}\right)_{2} \mathrm{SO}_{4}$ (187 mg of nitrogen) + wheat starch (13 g of dry matter (DM)); 3-4: control + antibiotic tested $(66 \mathrm{ppm}) ; 5-6$ (experimental): inoculum $+\left(\mathrm{NH}_{4}\right)_{2} \mathrm{SO}_{4}$ (187 mg of nitrogen) + wheat starch $(11.2 \mathrm{~g}$ of $\mathrm{DM})+$ peanut meal

Table I. lonophore antibiotics used.

lonophore Antibiotics Derivatives

\begin{tabular}{lll}
\hline Monensin $\left(\mathrm{M}_{1}\right)$ & $\begin{array}{l}\text { Monensin acetate }\left(\mathrm{M}_{2}\right), \\
\text { Monensin butyrate }\left(\mathrm{M}_{4}\right),\end{array}$ & $\begin{array}{l}\text { Monensin propionate }\left(\mathrm{M}_{3}\right), \\
\text { Monensin isobutyrate }\left(\mathrm{M}_{5}\right),\end{array}$ \\
& $\begin{array}{l}\text { Monensin urethane }\left(\mathrm{M}_{6}\right), \\
\text { Monensin ethyl }\left(\mathrm{M}_{9}\right),\end{array}$ & $\begin{array}{l}\text { Monensin lactone }\left(\mathrm{M}_{8}\right), \\
\text { Monensin methyl ether }\left(\mathrm{M}_{12}\right),\end{array}$ \\
& $\begin{array}{l}\text { Monensin isopropylidene }\left(\mathrm{M}_{13}\right) \\
\text { Oxolonomycin }\left(\mathrm{L}_{2}\right),\end{array}$ & Hydroxolonomycin $\left(\mathrm{L}_{3}\right)$ \\
Nonomycin $\left(\mathrm{L}_{1}\right)^{\text {a }}$ & Nigericic acid $\left(\mathrm{N}_{2}\right)$ & \\
Cationomycin $\left(\mathrm{C}_{1}\right)^{\text {b }}$ & Deacylated cationomycin $\left(\mathrm{C}_{2}\right)$
\end{tabular}

a Supplied by Sanofi Santé Animale (rue du Pr-Blayac, 34000 Montpellier, France).

b Produced by Kaken (Japan) and supplied by Sanofi Santé Animale (rue du Pr-Blayac, 34000 Montpellier, France).

${ }^{*} \mathrm{NaCl}=2.35 \mathrm{~g} ; \mathrm{KCl}=2.25 \mathrm{~g} ; \mathrm{MgCl}_{2}, 6 \mathrm{H}_{2} \mathrm{O}=0.5 \mathrm{~g} ; \mathrm{CaCl}_{2}, 2 \mathrm{H}_{2} \mathrm{O}=0.36 \mathrm{~g} ; \mathrm{NaHCO}_{3}=46.2 \mathrm{~g} ; \mathrm{Na}_{2} \mathrm{HPO}_{4}, 12 \mathrm{H}_{2} \mathrm{O}=$ $35.62 \mathrm{~g}$ dissolved in distilled water to a total volume of 5 liters. 
(1.8 $\mathrm{g}$ of DM providing $125 \mathrm{mg}$ of nitrogen); $7-8$ : experimental + antibiotic tested $(66$ ppm).

Each antibiotic was incubated at least 3 times with an interval of 3 days between each incubation series.

\section{Measurements}

A sample $(10 \mathrm{ml})$ was collected from the inoculum before incubation and from each fermenter after 1 and $6 \mathrm{~h}$ of fermentation. The $\mathrm{pH}$ was immediately measured and the samples were then centrifuged for $5 \mathrm{~min}$ at $2000 \times \mathrm{g}$. The supernatants were stored according to the methods described by Jouany and Thivend (1986) before analysis of ammonia nitrogen by Technicon method which uses reactions with sodium salicylate and sodium dichloroisocyanurate by means of an autoanalyzer, and of volatile fatty acids (VFA) by gas chromatography (Jouany, 1982). Gas production was determined at 1,4 and $6 \mathrm{~h}$, the composition of the mixture being determined by gas chromatography (Jouany and Senaud, 1978) on a gaseous sample collected from the exit vent of each fermenter after $4 \mathrm{~h}$ of incubation.

In vitro degradation of the peanut meal and an estimation of ammonia uptake by bacteria were calculated by the mathematical models established by Jouany and Thivend (1986). The degradation rate of nitrogen was estimated by comparing ammonia production from a control fermenter and an experimental fermenter. Both contained the same amount of fermentable organic matter, but protein was only added to the experimental fermenter. The nitrogen and sulfur microbial requirements were supplied by additional $\left(\mathrm{NH}_{4}\right)_{2} \mathrm{SO}_{4}$ in both fermenters. The ammonia uptake by bacteria is related to the amount of gas released, as demonstrated by Raab et al. (1983). The relation was established for each series on the control fermenter.

For each antibiotic, all data obtained were analyzed by comparison of means (two by two comparison using Student's $t$ test).

\section{Resuits}

pH and total VFA (Table II)

The $\mathrm{pH}$ of the liquid in fermenters measured at time $T_{0}$ was between 6.90 and 7.00. After $6 \mathrm{~h}$ of incubation, $\mathrm{pH}$ values were between 5.5 and 6 for the overall group of fermenters. Only 3 compounds were affected by the presence of ionophore antibiotics: the $M_{3}$ monensin derivative, lonomycin and $L_{2}$ derivative, for which $\mathrm{pH}$ values were significantly higher than those of controls without antibiotic. In correlation with this, the total VFA production in fermenters which received these 3 ionophores was significantly lower than that of control fermenters. In contrast, 2 derivatives of monensin $\left(M_{6}\right.$ and $\left.M_{12}\right)$ increased the total VFA concentration in the presence of protein nitrogen. The other ionophores did not modify this parameter for the 2 nitrogen sources considered.

The presence of peanut meal in the experimental fermenters led to a pronounced increase $(+20 \%)$ in the total VFA production at the end of incubation.

\section{Molar composition of VFA (Table III)}

One of the well-established actions of ionophore antibiotics is their ability to stimulate production of propionic acid. Our results showed two types of compounds : 1) those which increased the propionate concentration: approximately $15 \%$ for monensin $\left(M_{1}\right)$, its $M_{4}$ and $M_{6}$ derivatives, nigericin, cationomycin and lysocellin. The monensin $M_{3}$ and $M_{10}$ derivatives had the same effects but to a lesser degree (+ $9 \%$ ). Lonomycin and its $L_{2}$ and $L_{3}$ derivatives increased the molar percentage of propionic acid to a slightly higher level (+ 20\%). For all these compounds, with the exception of cationomycin, this increase occurred at the expense of acetic acid. A monensin derivative, monensin isobutyrate $\left(\mathrm{M}_{5}\right)$ was clearly distinguished from the other ionophores, since it caused an increase of $26 \%$ in the production of propionate with 
Table II. Effect of different ionophore antibiotics on $\mathrm{pH}$ and VFA concentration at the end of incubation time.

\begin{tabular}{|c|c|c|c|c|c|c|c|c|}
\hline \multirow[t]{2}{*}{$\left.\right|^{1}{ }^{1}$} & \multicolumn{3}{|c|}{$p H$} & \multicolumn{5}{|c|}{$V F A(m m o l / l))^{2}$} \\
\hline & $c_{1}$ & $c_{2}$ & $E_{1}$ & $E_{2}$ & $C_{1}$ & $c_{2}$ & $E_{1}$ & $E_{2}$ \\
\hline$M_{1}$ & 5.7 & 5.7 & 5.6 & 5.6 & $108.2^{a}$ & $110.4 \mathrm{a}$ & $139.4 \mathrm{~b}$ & $135.3^{b}$ \\
\hline$M_{2}$ & 6.0 & 6.0 & 5.8 & 5.8 & 101.7 & 111.5 & 114.2 & 122.8 \\
\hline$M_{3}$ & $5.7^{\mathrm{a}}$ & $6.0^{b}$ & $5.6^{a}$ & $5.8^{a}$ & $127.2^{b}$ & $102.4^{a}$ & $126.0^{b}$ & $117.9 \mathrm{c}$ \\
\hline $\mathrm{M}_{4}$ & 6.0 & 6.0 & 5.7 & 5.8 & 100.1 a & $103.3^{a}$ & $122.3^{b}$ & $121.5^{b}$ \\
\hline$M_{5}^{4}$ & 6.2 & 6.1 & 5.9 & 5.9 & 95.9 a & $100.0^{a b}$ & 115.9 bc & $119.9 \mathrm{c}$ \\
\hline$M_{6}$ & $5.9 \mathrm{a}$ & $5.8 \mathrm{a}$ & $5.6 a b$ & $5.6^{\circ}$ & 100.9 a & $109.3 \mathrm{a}$ & $126.4^{b}$ & $136.5^{c}$ \\
\hline$M_{8}$ & $6.3^{\mathrm{a}}$ & $6.2 \mathrm{a}$ & $5.8 \mathrm{~b}$ & $5.7^{b}$ & 89.4 a & 93.4 a & $117.4^{b}$ & $123.0^{b}$ \\
\hline$M_{g}$ & 5.1 & 5.1 & 5.1 & 5.1 & $125.5^{\mathrm{a}}$ & $125.7^{\mathrm{a}}$ & $140.8^{b}$ & $146.4^{b}$ \\
\hline$M_{10}$ & 5.9 ac & $5.8 \mathrm{a}$ & $5.6 \mathrm{bc}$ & $5.5 \mathrm{~b}$ & $102.7 \mathrm{a}$ & $104.1^{\mathrm{a}}$ & $123.0^{b}$ & $123.7^{b}$ \\
\hline$M_{12}$ & 5.9 & 6.1 & 5.7 & 5.6 & $101.2^{a}$ & $100.1 \mathrm{a}$ & $121.6^{b}$ & $129.2^{c}$ \\
\hline$M_{13}$ & 5.1 & 5.1 & 5.1 & 5.1 & 119.5 a & $113.1 \mathrm{a}$ & $137.3 \mathrm{~b}$ & $139.6^{b}$ \\
\hline$L_{1}$ & $6.2^{a}$ & $6.3 \mathrm{a}$ & $5.8^{b}$ & $6.1^{\mathrm{c}}$ & $93.0 \mathrm{a}$ & 96.1 ac & $121.5^{b}$ & $114.3^{c}$ \\
\hline $\mathrm{L}_{2}$ & $6.1^{a}$ & $6.5^{b}$ & $5.7^{c}$ & $6.1 \mathrm{a}$ & $96.4^{a}$ & $98.5^{a}$ & $126.5^{b}$ & $118.3^{c}$ \\
\hline$L_{3}$ & 5.9 & 5.9 & 5.7 & 5.7 & 101.8 & 103.0 & 117.7 & 113.9 \\
\hline $\mathrm{N}_{1}$ & 6.1 & 6.1 & 6.0 & 6.1 & $98.1^{a}$ & 101.9 a & $117.5^{b}$ & $118.1^{\mathrm{b}}$ \\
\hline $\mathrm{N}_{2}$ & 6.0 & 6.0 & 5.8 & 5.7 & $94.3^{a}$ & $99.3^{a}$ & $117.5^{\mathrm{b}}$ & $122.1^{b}$ \\
\hline $\mathrm{C}_{1}$ & 5.8 a & $5.8 \mathrm{a}$ & $5.5^{b}$ & $5.6 \mathrm{a}$ & $108.4^{a}$ & $112.5^{a}$ & $131.9^{b}$ & $131.2^{b}$ \\
\hline $\mathrm{C}_{2}$ & $5.8 \mathrm{a}$ & $6.0^{\mathrm{b}}$ & $5.6 \mathrm{a}$ & $5.6 \mathrm{a}$ & $108.7^{a}$ & $100.9^{a}$ & $132.3^{b}$ & $134.0^{b}$ \\
\hline Ly & 5.6 & 5.8 & 5.6 & 5.5 & 117.9 a & 120.9 ac & $130.4 b c$ & $135.1^{b}$ \\
\hline
\end{tabular}

$\mathrm{C}_{1}=$ inoculum + starch $+\left(\mathrm{NH}_{4}\right)_{2} \mathrm{SO}_{4} ; \mathrm{C}_{2}=\mathrm{C}_{1}+$ antibiotic.

$\mathrm{E}_{1}$ = inoculum + starch $+\left(\mathrm{NH}_{4}\right)_{2} \mathrm{SO}_{4}+$ peanut meal. $\mathrm{E}_{2}=\mathrm{E}_{1}+$ antibiotic.

1 lonophore antibiotics (see Table I).

2 Concentration at the end of incubation time.

Means with different superscripts on a line are significantly different $(P<0.05)$.

only an $8 \%$ acetate decrease; 2 ) those which induced no significant modification in the proportion of propionic acid : the $M_{2}, M_{8}, M_{9}, M_{12}$ and $M_{13}$ monensin derivatives, nigericic acid $\left(\mathrm{N}_{2}\right)$ and the deacylated cationomycin $\left(\mathrm{C}_{2}\right)$. These compounds had no effect on acetic acid molar proportion either.

The proportions of butyric acid, not reported here, significantly decreased with only 4 compounds: lonomycin and its derivatives and cationomycin. Only monensin significantly reduced the proportion of isobutyric acid; this compound, the $\mathrm{M}_{3}$ derivative and lonomycin also caused a decrease in the proportion of isovaleric acid.

Gas production and composition (Table IV)

Gas production measured after $6 \mathrm{~h}$ of incubation was significantly decreased by lonomycin and its $L_{2}$ derivative and by nigericin. The other compounds, and, in particular, monensin and its derivatives, had no effect on total gas production: this 
Table III. Effect of different ionophore antibiotics on acetate and propionate molar proportions in VFA mixture at the end of incubation.

\begin{tabular}{|c|c|c|c|c|c|c|c|c|}
\hline \multirow[t]{2}{*}{$I^{1}$} & \multicolumn{4}{|c|}{ Acetate molar proportion } & \multicolumn{4}{|c|}{ Propionate molar proportion } \\
\hline & $C_{1}$ & $c_{2}$ & $E_{1}$ & $E_{2}$ & $C_{1}$ & $C_{2}$ & $E_{1}$ & $E_{2}$ \\
\hline$M_{1}$ & $67.5^{a}$ & $65.3^{b}$ & $64.5^{b}$ & $60.9 c$ & $21.4^{\mathrm{a}}$ & $24.6^{b}$ & $23.2^{c}$ & $27.4^{d}$ \\
\hline$M_{2}$ & 66.7 & 66.8 & 66.6 & 64.9 & 21.8 & 21.9 & 20.9 & 22.9 \\
\hline$M_{3}$ & $66.8 \mathrm{a}$ & $65.3^{b}$ & $64.7^{b}$ & $62.6 \mathrm{c}$ & 21.2 a & $23.5^{b}$ & 22.1 a & $24.3^{b}$ \\
\hline$M_{4}$ & $69.3 \mathrm{a}$ & 66.9 a & 66.8 ab & $64.2 \mathrm{~b}$ & $19.1 \mathrm{a}$ & $22.2 \mathrm{~b}$ & 19.9 a & $23.0^{b}$ \\
\hline$M_{5}$ & 69.6 a & $65.1 \mathrm{~b}$ & $67.1^{\mathrm{c}}$ & $61.6 \mathrm{~d}$ & $18.8^{a}$ & 24.4 ab & $19.2^{a}$ & $26.1^{b}$ \\
\hline$M_{6}$ & 69.6 a & $68.1^{\mathrm{b}}$ & $67.1^{\mathrm{c}}$ & $64.5^{d}$ & $18.8^{a}$ & $21.4 \mathrm{~b}$ & 19.5 a & $22.9^{c}$ \\
\hline$M_{8}$ & $69.3^{a}$ & $68.0 \mathrm{ab}$ & $66.3^{b}$ & $65.6^{b}$ & 18.1 & 19.3 & 19.8 & 20.1 \\
\hline $\mathrm{M}_{9}$ & 67.1 & 64.9 & 62.8 & 63.6 & 20.1 & 23.1 & 24.2 & 22.6 \\
\hline$M_{10}$ & $68.8^{a}$ & $66.9 \mathrm{~b}$ & $66.3^{b}$ & $63.5^{c}$ & 20.1 a & $21.8^{b}$ & $20.9^{b}$ & $23.6^{c}$ \\
\hline$M_{12}$ & $68.5^{a}$ & $67.9 \mathrm{a}$ & $66.2^{c}$ & $64.8 \mathrm{~d}$ & 18.4 & 19.3 & 19.2 & 19.4 \\
\hline$M_{13}$ & $66.0^{\mathrm{a}}$ & $66.0^{a}$ & $63.7^{b}$ & $63.4^{b}$ & $21.5^{a}$ & $21.4 \mathrm{a}$ & $23.2^{b}$ & $23.2^{b}$ \\
\hline $\mathrm{L}_{1}$ & 68.9 a & $66.3^{b}$ & $65.7^{\circ}$ & $62.7^{c}$ & $17.7 \mathrm{a}$ & $22.2 \mathrm{abc}$ & 19.1 ab & $23.8 \mathrm{c}$ \\
\hline$L_{2}$ & $67.6 \mathrm{a}$ & $68.4 \mathrm{a}$ & $66.1^{b}$ & $62.8^{c}$ & $18.5^{a}$ & $20.8^{b}$ & $18.7^{a}$ & $24.3^{c}$ \\
\hline$L_{3}$ & $68.5^{a}$ & $65.8^{\mathrm{b}}$ & $65.9^{b}$ & $62.5^{\mathrm{c}}$ & $18.9 \mathrm{a}$ & $23.2^{b}$ & $19.8^{c}$ & $24.2^{b}$ \\
\hline$N_{1}$ & $67.4 \mathrm{a}$ & $65.9 \mathrm{~b}$ & $65.0^{\mathrm{b}}$ & $63.0^{c}$ & $19.5 \mathrm{a}$ & $22.4^{b}$ & 20.0 a & $23.3^{b}$ \\
\hline $\mathrm{N}_{2}$ & 68.9 a & $70.0^{a}$ & $66.5^{b}$ & $66.6^{b}$ & 20.1 & 19.5 & 21.3 & 20.4 \\
\hline$c_{1}$ & 66.6 & 65.2 & 65.2 & 63.4 & $21.2^{a}$ & $24.0^{b}$ & $21.5 \mathrm{a}$ & $24.3^{b}$ \\
\hline $\mathrm{C}_{2}$ & 68.9 a & $69.0 \mathrm{a}$ & $66.4^{\circ}$ & $66.3^{b}$ & $18.9 \mathrm{ab}$ & $19.3 \mathrm{a}$ & $20.7^{b}$ & $20.9 b$ \\
\hline Ly & 67.6 ac & $63.0^{b}$ & 64.3 bc & $61.3^{b}$ & $21.1^{a}$ & $25.6^{b}$ & $23.1 \mathrm{a}$ & $26.5 b$ \\
\hline
\end{tabular}

$\mathrm{C}_{1} ; \mathrm{C}_{2} ; \mathrm{E}_{1} ; \mathrm{E}_{2}$ : see table II.

1 lonophore antibiotics (see Table I).

Means with different superscripts on a line are significantly different $(P<0.05)$.

behaviour was not influenced by the nature of the nitrogen sources. The presence of peanut meal markedly increased gaseous production $(+15 \%)$ in the overall group of fermenters.

Monensin and its $M_{2}, M_{3}$ and $M_{4}$ derivatives had very marked inhibitory effects on methanogenesis, which was shown by the significant increases in the $\mathrm{CO}_{2} / \mathrm{CH}_{4}$ ratios in the gaseous mixture. The $\mathrm{M}_{5}$ derivative showed the highest activity, since it increased this ratio by $41.5 \%$. Lonomycin increased the ratio to an extent comparable to that of monensin; the $L_{2}$ derivative and lysocellin also caused positive alterations in this ratio but to a lesser degree.

\section{Degradability of the peanut meal nitrogen} (Table V)

An interesting property of ionophore antibiotics is their capacity to reduce protein degradation to the $\mathrm{NH}_{3}$ stage in the rumen. Of the compounds tested, the most active were lysocellin $(-57 \%), M_{2}$ $(-56 \%)$ and $M_{3}$ derivatives $(-49 \%)$, as well as lonomycin $(-41 \%)$, its $L_{2}$ derivative $(-45 \%)$ and monensin $(-38 \%)$. Catio- 
Table IV. Effect of different ionophore antibiotics on gas production and composition for 6 hours of incubation.

\begin{tabular}{|c|c|c|c|c|c|c|c|c|}
\hline \multirow[t]{2}{*}{$I A^{1}$} & \multicolumn{3}{|c|}{$\operatorname{Gas}^{2}(\mathrm{~m} /)$} & \multicolumn{5}{|c|}{$\mathrm{CO}_{2} / \mathrm{CH}_{4}$} \\
\hline & $C_{1}$ & $c_{2}$ & $E_{1}$ & $E_{2}$ & $c_{1}$ & $c_{2}$ & $E_{1}$ & $E_{2}$ \\
\hline$M_{1}$ & 1295 a & $1220 a$ & $1508^{b}$ & $1435 \mathrm{~b}$ & $4.9 \mathrm{a}$ & $6.6^{b}$ & $4.3 \mathrm{a}$ & $5.1^{\mathrm{a}}$ \\
\hline$M_{2}$ & $1147 a$ & $1117 \mathrm{a}$ & $1420^{b}$ & $1305^{b}$ & $3.8 \mathrm{a}$ & $4.1 \mathrm{a}$ & $3.3 \mathrm{~b}$ & $3.8 \mathrm{c}$ \\
\hline$M_{3}^{2}$ & 1232 a & 1127 a & $1140^{c} \mathrm{c}$ & $1307^{d}$ & 3.9 & 4.4 & 3.8 & 4.1 \\
\hline$M_{4}$ & 1213 a & $1120 \mathrm{a}$ & $1422 \mathrm{~b}$ & $1365^{b}$ & $4.3 \mathrm{a}$ & $5.9 \mathrm{~b}$ & $3.8 \mathrm{a}$ & $4.2^{\mathrm{a}}$ \\
\hline$M_{5}$ & 1070 & 920 & 1353 & 1275 & $4.8^{\mathrm{a}}$ & $6.3^{b}$ & $3.6 \mathrm{c}$ & $5.1 \mathrm{a}$ \\
\hline$M_{6}$ & $1118 \mathrm{a}$ & $1143 a$ & $1315^{b}$ & $1412^{c}$ & $5.3 \mathrm{a}$ & $5.1 \mathrm{a}$ & $4.0^{b}$ & $3.9 \mathrm{~b}$ \\
\hline$M_{8}$ & $1030^{a}$ & 1025 a & $1276^{b}$ & $1315^{b}$ & 5.3 & 6.5 & 4.6 & 4.3 \\
\hline $\mathrm{M}_{9}$ & $1380 a b$ & $1325 \mathrm{a}$ & $1467 b c$ & $1540 \mathrm{c}$ & 3.9 & 4.5 & 4.1 & 4.1 \\
\hline$M_{10}$ & $1122^{a}$ & 1160 a & $1356^{b}$ & 1427 b & $4.7 \mathrm{a}$ & $5.3^{b}$ & 4.2 a & $4.2 \mathrm{a}$ \\
\hline$M_{12}$ & $1115^{a}$ & $1103^{a}$ & $1318^{b}$ & $1402 b$ & 4.6 & 4.7 & 4.1 & 3.9 \\
\hline$M_{13}$ & $1333 \mathrm{a}$ & $1295 \mathrm{a}$ & $1538 \mathrm{~b}$ & $1533^{b}$ & $4.8 \mathrm{a}$ & $5.0^{a}$ & $4.0^{b}$ & $3.8 \mathrm{~b}$ \\
\hline $\mathrm{L}_{1}$ & 1025 a & 940 a & $1335 \mathrm{~b}$ & $1175^{c}$ & $5.1 \mathrm{abc}$ & $6.3 \mathrm{ad}$ & $4.0 \mathrm{~b}$ & $5.1 \mathrm{~cd}$ \\
\hline$L_{2}$ & $1140^{a}$ & $925^{b}$ & $1393^{c}$ & 1182 a & $5.2 \mathrm{a}$ & $4.7 \mathrm{abc}$ & $3.7 \mathrm{c}$ & $4.8 \mathrm{ab}$ \\
\hline $\mathrm{L}_{3}$ & 1137 a & 1066 a & $1367^{b}$ & $1323 \mathrm{~b}$ & 4.4 & 4.9 & 3.9 & 4.5 \\
\hline$N_{1}$ & 1328 a & $1242 b$ & $1522^{c}$ & $1420^{d}$ & 3.9 & 3.8 & 3.5 & 3.6 \\
\hline $\mathrm{N}_{2}$ & 1015 a & $1050 \mathrm{a}$ & $1314 \mathrm{~b}$ & $1290^{b}$ & 5.5 & 5.1 & 4.1 & 4.6 \\
\hline $\mathrm{C}_{1}$ & $1126^{a}$ & $\$ 1522^{a}$ & $1410^{b}$ & $1382^{b}$ & $5.4 a c$ & $5.8 \mathrm{a}$ & $3.9 \mathrm{~b}$ & $4.5 b c$ \\
\hline $\mathrm{C}_{2}$ & 1217 a & 1096 a & $1438^{b}$ & $1472^{b}$ & $4.6 \mathrm{ac}$ & $5.2^{a}$ & $4.0 \mathrm{~b}$ & $3.4 \mathrm{c}$ \\
\hline Ly & $1205^{a}$ & $1133^{b}$ & $1363 \mathrm{c}$ & $1315^{c}$ & $4.4 \mathrm{a}$ & $5.5 \mathrm{~b}$ & $3.6 \mathrm{c}$ & $4.7 \mathrm{ab}$ \\
\hline
\end{tabular}

$\mathrm{C}_{1} ; \mathrm{C}_{2} ; \mathrm{E}_{1} ; \mathrm{E}_{2}$; see Table II.

1 lonophore antibiotics (see Table l).

2 Gas production during $6 \mathrm{~h}$ of incubation.

Means with different superscripts on a line are significantly different $(P<0.05)$.

nomycin, like the $\mathrm{M}_{5}$ derivative, had a less marked effect on this parameter $(-18 \%)$.

\section{Bacterial ammonia uptake (Table V)}

Bacterial ammonia uptake was calculated from 1 to $6 \mathrm{~h}$ of incubation time. This determination in the experimental fermenters took into account the degradation of peanut meal during the time interval. In comparison with the non-protein nitrogen, the presence of peanut meal in the experimental fermenters improved nitrogen fixation by bacteria by approximately $15-20 \%$.
The main disadvantage of ionophore antibiotics observed in vitro with respect to rumen fermentations was their negative effect on bacterial ammonia uptake. This was particularly marked with lonomycin $(-48 \%)$ and its $L_{2}$ derivative $(-40 \%)$, and with lysocellin (-38\%). The $M_{2}, M_{3}$ and $M_{4}$ esters of monensin had a similar depressive action (-32\%) which was superior to that of the original molecule $(-24 \%)$. Cationomycin affected ammonia uptake in an identical manner to that of monensin. An interesting characteristic of the $M_{5}$ derivative was its very weak negative action in this parameter. Only the $\mathrm{M}_{8}$ derivative improved bacterial ammonia 
Table V. Effect of different ionophore antibiotics on protein degradability and bacterial ammonia uptake during $6 \mathrm{~h}$ of incubation.

\begin{tabular}{|c|c|c|c|c|c|c|}
\hline \multirow[t]{2}{*}{$\mid A^{1}$} & \multicolumn{2}{|c|}{ Protein degradability (\%) } & \multicolumn{4}{|c|}{ Bacterial ammonia uptake 2} \\
\hline & $E_{1}$ & $E_{2}$ & $c_{1}$ & $C_{2}$ & $E_{1}$ & $E_{2}$ \\
\hline$M_{1}$ & $68.7^{a}$ & $42.4^{b}$ & $107.2 \mathrm{ab}$ & $80.9 \mathrm{ab}$ & 129.2 a & $98.3^{b}$ \\
\hline$M_{2}^{\prime}$ & $69.0 \mathrm{a}$ & $30.5 \mathrm{~b}$ & $97.0^{a}$ & $67.3^{\circ}$ & $124.7^{\mathrm{c}}$ & $81.6 \mathrm{ab}$ \\
\hline$M_{3}$ & $57.9^{a}$ & $29.4^{b}$ & 95.8 a & $65.1^{b}$ & $115.8^{c}$ & 78.2 ab \\
\hline$M_{4}$ & $58.6 \mathrm{a}$ & $46.6^{b}$ & $95.1 \mathrm{a}$ & $62.9 \mathrm{~b}$ & $113.9 \mathrm{c}$ & $80.3^{a}$ \\
\hline $\mathrm{M}_{5}$ & $63.3^{a}$ & $51.2^{b}$ & $73.4^{\mathrm{a}}$ & $60.6 \mathrm{ab}$ & $98.5^{b}$ & $90.5^{b}$ \\
\hline$M_{6}$ & 62.0 & 64.2 & $96.5 \mathrm{a}$ & $78.1^{\mathrm{b}}$ & $120.0^{c}$ & $99.7 \mathrm{a}$ \\
\hline$M_{8}$ & 57.1 & 55.6 & 68.9 a & $88.0 \mathrm{abc}$ & $90.7^{b}$ & $119.4^{c} \mathrm{c}$ \\
\hline$M_{9}$ & 61.7 & 56.7 & $112.1 \mathrm{a}$ & $86.1^{b}$ & $122.7^{c}$ & $101.1^{d}$ \\
\hline$M_{10}$ & $63.7 \mathrm{a}$ & $46.5^{b}$ & 91.9 a & $82.8 \mathrm{a}$ & $112.0^{\mathrm{b}}$ & $103.5^{b}$ \\
\hline$M_{12}$ & 58.0 & 55.0 & 78.9 a & $68.8^{a}$ & $98.7^{b}$ & $92.8^{b}$ \\
\hline$M_{13}$ & 62.5 & 65.4 & $110.6^{a}$ & $114.2^{\mathrm{a}}$ & $131.1^{b}$ & $135.4^{b}$ \\
\hline$L_{1}$ & $56.2 \mathrm{a}$ & $33.1^{b}$ & 69.8 a & $38.1^{\mathrm{b}}$ & $97.0 \mathrm{c}$ & $49.7 a b$ \\
\hline $\mathrm{L}_{2}$ & $59.2^{a}$ & $32.8^{b}$ & $73.2 a b c$ & $41.9 \mathrm{a}$ & $94.8^{b}$ & $57.0^{\mathrm{c}}$ \\
\hline$L_{3}$ & $67.0 \mathrm{a}$ & $45.4 \mathrm{~b}$ & 92.4 a & $62.0 \mathrm{~b}$ & $110.4 \mathrm{~b}$ & $78.7 c$ \\
\hline$N_{1}$ & 60.5 & 55.0 & $89.6 \mathrm{a}$ & $65.1 \mathrm{bc}$ & 105.7 a & $71.8^{c}$ \\
\hline $\mathrm{N}_{2}$ & $62.5^{a}$ & $49.8^{b}$ & $99.5 \mathrm{a}$ & $76.4^{b}$ & $130.7^{c}$ & $92.6^{a}$ \\
\hline $\mathrm{C}_{1}$ & $70.8^{a}$ & $57.8^{b}$ & 99.5 a & $76.4^{b}$ & $130.7^{c}$ & $92.6^{a}$ \\
\hline $\mathrm{C}_{2}$ & 68.6 & 67.2 & $115.3 \mathrm{ac}$ & $91.6 \mathrm{a}$ & $136.6^{b}$ & $121.5^{c}$ \\
\hline Ly & $66.7 \mathrm{a}$ & $28.6^{b}$ & 97.8 a & $59.6^{b}$ & $112.4^{c} \mathrm{c}$ & $70.9^{b}$ \\
\hline
\end{tabular}

$\mathrm{C}_{1} ; \mathrm{C}_{2} ; \mathrm{E}_{1} ; \mathrm{E}_{2}$ : see Table II.

1 lonophore antibiotics (see Table I).

2 Incorporated nitrogen $(\mathrm{mg})$ during $6 \mathrm{~h}$.

Means with different superscripts on a line are significantly different $(P<0.05)$.

uptake $(+20 \%)$. This was the only parameter on which this derivative had a significant effect.

The action of ionophores on bacterial proteosynthesis, estimated from ammonia uptake, was not altered by the nature of the nitrogen introduced into the fermenters.

\section{Discussion and Conclusion}

The addition of monensin to the fermenters induced an increase in the proportion of propionic acid, at the expense of that of acetic acid, both in in vitro (Chalupa, 1980; Stanier and Davies, 1981) and in vivo experiments (Chalupa, 1977; Jouany and Senaud, 1978). Its lack of effect on total VFA and gas production is more debatable (Durand, 1982). We were able to confirm this for the two nitrogen sources used. The inhibitory effect of this molecule on methanogenesis, previously demonstrated in vitro by Bartley et al. (1979) and in vivo by Jouany and Senaud (1978) and Benz and Johnson (1982), confirms the effect observed on the molar composition of the 
VFA mixture. The decrease in the nitrogen degradability of peanut meal $(-38 \%)$ is suggestive of a protective effect with respect to dietary proteins in the rumen as discussed by Durand (1982). Its depressive action on microbial synthesis $(-24 \%)$ was also demonstrated in vitro by Van Nevel and Demeyer (1977) and in vivo by Van Nevel and Demeyer (1979) and Muntifering et al. (1981).

We determined the effect of other ionophore antibiotics on the orientation and intensity of rumen fermentations, whose the complex activity on alkaline cations has been previously studied (Gaboyard, 1987). Results obtained with these different molecules are presented in Table VI. A common characteristic of natural ionophore antibiotics (lonomycin, nigericin, cationomycin and lysocellin) is their ability, like monensin, to improve the

Table VI. Influence of different ionophore antibiotics on some rumen end products of fermentation, protein degradability and bacterial ammonia uptake.

\begin{tabular}{|c|c|c|c|c|c|c|c|}
\hline & VFA (1) & $C_{2}(2)$ & $c_{3}(3)$ & Gas & $\mathrm{CO}_{2} / \mathrm{CH}_{4}$ & $D(4)$ & $\mathrm{BAU}(5)$ \\
\hline MI & $=$ & $\checkmark v$ & $M$ & $\mathbf{x}$ & $\mu$ & ज & 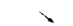 \\
\hline M2 & $=$ & $=$ & $=$ & $\mathbf{x}$ & $\prime$ & $\therefore$ & $\therefore$ \\
\hline$M \overline{3}$ & $x$ & $x$ & $\mu$ & $=$ & $x$ & 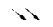 & 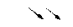 \\
\hline M4 & $=$ & $=$ & $\Leftrightarrow$ & $=$ & 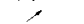 & 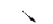 & 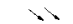 \\
\hline M5 & $=$ & $\therefore$ & 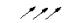 & $=$ & $M$ & $\checkmark$ & \\
\hline M6 & 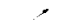 & $\because$ & $\infty$ & $=$ & $=$ & $=$ & 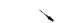 \\
\hline MB & $=$ & $=$ & $=$ & $=$ & $=$ & $=$ & 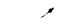 \\
\hline M9 & $x$ & $x$ & $=$ & $=$ & $=$ & $=$ & $\checkmark$ \\
\hline MHO & $=$ & $x$ & 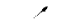 & $=$ & $=$ & ' & $=$ \\
\hline$M 12$ & 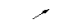 & $=$ & $=$ & $=$ & $=$ & $=$ & $=$ \\
\hline$M 13$ & $=$ & $=$ & $=$ & $=$ & $=$ & $=$ & $=$ \\
\hline LI & $=$ & $x$ & S & $v$ & $\Leftrightarrow$ & $\therefore$ & $\infty x$ \\
\hline L2 & $=$ & $\checkmark$ & $\Rightarrow$ & $\therefore$ & 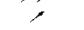 & $\therefore$ & $\therefore$ \\
\hline L3 & $=$ & 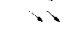 & 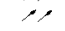 & $=$ & $=$ & $\therefore$ & $\infty$ \\
\hline $\mathbf{N} \mid$ & $=$ & 、 & $\mu$ & $v$ & $=$ & $=$ & 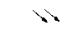 \\
\hline N2 & $x$ & $=$ & $=$ & $=$ & $=$ & $\checkmark$ & $v$ \\
\hline $\mathrm{Cl}$ & $=$ & . & 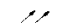 & $=$ & $=$ & $x$ & 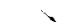 \\
\hline$c 2$ & $=$ & $=$ & $=$ & $=$ & $=$ & $=$ & $y$ \\
\hline LY & $=$ & 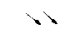 & $M$ & $=$ & $\gamma$ & $\infty$ & 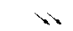 \\
\hline
\end{tabular}

(1) Volatile fatty acid production.

(2) Acetate molar proportion

(3) Propionate molar proportion

(4) Protein degradability.

(5) Bacterial ammonia uptake.

= no effect; $\nearrow$ increase; $\searrow$ reduction. production of propionic acid at the expense of acetic acid.

Lonomycin and lysocellin are also similar to monensin in that they inhibit methanogenesis and degradation of proteins. However, the high toxicity of lonomycin (lethal dose, $\mathrm{LD}_{50}$, after oral administration on mice, is $10 \mathrm{mg} / \mathrm{kg}$ of live weight) limits its practical use in animals. In contrast, lysocellin presents the distinctive characteristic of being half as toxic as monensin (Gaboyard, 1987). The depressive effect of lysocellin on bacterial ammonia uptake $(-38 \%)$, which limits the interest of this molecule, could be partly compensated for by its protective action with respect to dietary protein nitrogen. Of the molecules tested, lysocellin presented the greatest capacity to reduce degradation of peanut meal nitrogen $(-57 \%)$. These results could explain its positive action on zootechnical performances of growing cattle observed by Preston et al. (1985).

For nigericin, data obtained on VFA and gas production were similar to those given by Caffarel-Mendez et al. (1986), except for methane production, which was not reduced in our experiment. Nigericin strongly inhibited bacterial ammonia uptake and had no protective effect with respect to dietary protein digestion in the rumen.

Cationomycin had effects similar to those of monensin on most fermentation parameters. However, the protective action against peanut meal degradation was weaker than that of monensin. Unlike other tested ionophores, cationomycin had a low toxicity. The lethal dose $\left(L D_{50}\right)$ of cationomycin after oral administration in mice was $1600 \mathrm{mg} / \mathrm{kg}$ compared with 150 to $170 \mathrm{mg} / \mathrm{kg}$ for monensin (Gaboyard, 1987). These results indicate that cationomycin could be considered as a possible growth promoter, competing with monensin and lasalocid. 
The monensin derivatives, $M_{8}, M_{9}, M_{12}$ and $M_{13}$, which had no action on microbial metabolism, also have weak ionophore properties (Gaboyard, 1987). The $M_{2}, M_{3}, M_{4}$ and $M_{5}$ ester derivatives and the $M_{6}$ urethane derivative were the most active compounds on rumen fermentation parameters. Monensin isobutyrate $\left(M_{5}\right)$ in particular acted very favorably on these parameters $\left(\mathrm{C}_{3}, \mathrm{C}_{2}\right.$, $\mathrm{CO}_{2} / \mathrm{CH}_{4}$ ). Its protective effect on peanut meal proteins was lower than that of monensin. In contrast the $\mathrm{M}_{5}$ derivative had no influence on bacterial ammonia uptake.

These observations demonstrate that by modification of the chemical structure, it is possible to obtain compounds possessing different properties from those of natural molecules. The toxicity of the $\mathrm{M}_{5}$ derivative determined on mice appears very much higher than that of monensin and is the main limiting factor to its future practical use.

The opening of the terminal cycle of lonomycin leads to the formation of oxolonomycin $\left(L_{2}\right)$. The derivative presents properties similar to those of the parent molecule with respect to rumen fermentation. In contrast, its toxicity measured on mice was markedly lower than that of lonomycin and only half that of monensin. This molecule is a potential growth promoter.

Cationomycin has an aromatic ester branched on a classical polyether-type chain (Gaboyard, 1987), which appears to confer its original properties on this molecule. Thus deacylated cationomycin $\left(\mathrm{C}_{2}\right)$, which differs from the natural molecule only by the absence of this ester, did not possess any activity on rumen microbial metabolism, but its toxicity was comparable to that of monensin and it had very marked ionophore properties with respect to potassium (Gaboyard, 1987). It appears to be well established that the growth promoter activity is related to the complexing potential of the molecules, but in this case this property is not sufficient to explain the modification observed.

The results of our study have demonstrated that some derivatives are more active than natural compounds (i.e., monensin isobutyrate). Derivatization can also be used to reduce the toxicity of ionophores (oxolonomycin compared to lonomycin) without altering their activity on rumen fermentation. However, we could not relate the chemical structure of a molecule to its activity as a growth promoter. Three of the compounds tested (oxolonomycin, lysocellin and cationomycin) presented some beneficial effects on the orientation of rumen fermentation and a weak or moderate toxicity for mice, assuming their potential use as growth promoters for ruminants. It should be kept in mind, however, that determinations were carried out in vitro with non-adapted inocula. It is therefore difficult to extrapolate these results to animals. In fact, Herod et al. (1979) and De Jong and Berschauer (1983) demonstrated that the orientation of fermentation in the presence of ionophores could differ, according to whether the inocula were obtained from animals that were adapted or not to these molecules.

\section{Acknowledgments}

The authors wish to thank the Société Sanofi Santé Animale for their financial participation in these studies. They are also grateful to L. L'Hotelier, M. Fabre and P. Pichon for animal care and technical assistance. 


\section{References}

Bartley E.E., Herod E.L., Bechtle R.M., Sapienza D.A. \& Brent B.A. (1979) Effect of monensin or lasalocid, with or without niacin or amicloral on rumen fermentation and feed efficiency. J. Anim. Sci. 49, 1066-1075

Benz D.A. \& Johnson D.E. (1982) The effect of monensin on energy partitioning by forage-fed steers. J. Anim. Sci. 55 (suppl. 1), 491 (Abstr.)

Bergen W.G. \& Bates D.B. (1984) lonophores: their effect on production efficiency and mode of action. J. Anim. Sci. 58, 1465-1483

Caffarel-Mendez S., Jouany J.P. \& Demuynck C. (1986) Etude in vitro de quelques antibiotiques ionophores et de certains dérivés. I. Action sur les produits de la fermentation dans le rumen. Reprod. Nutr. Dév. 26, 1295-1303

Chalupa W. (1977) Manipulating rumen fermentation. J. Anim. Sci. 45, 585-599

Chalupa W. (1980) Chemical control of rumen microbial metabolism. In: Digestive Physiology and Metabolism in Ruminants (Ruckebusch Y. \& Thivend P., eds.), MTP Press Ltd, Lancaster, UK, pp. 325-347

De Jong A. \& Berschauer F. (1983) Adaptation effects of ionophores on rumen fermentation. S. Afr. J. Anim. Sci. 13, 67-70

Durand M. (1982) Orientation du métabolisme du rumen au moyen des additifs. Ann. Zootech. 31, 47-76

Gaboyard C. (1987) Etude de dérivés des antibiotiques ionophores, monensine, lonomycine, cationomycine. Complexation du $\mathrm{Na}^{+}$et $\mathrm{K}^{+}$. Toxicité. Activité anticoccidienne et facteur de croissance. Thèse de Docteur Ingénieur. Univ. de Clermont-Ferrand II, Clermont-Ferrand, France 243 pp.

Herod E.L., Bartley E.E., Davidovitch A., Bechtle R.M., Sapienza D.A. \& Brent B.E. (1979) Effect of adaptation to monensin or lasalocid on rumen fermentation in vitro and the effect of these drugs on heifer growth and feed efficiency. J. Anim. Sci. 49 (suppl. 1), 374 (Abstr.)

Jouany J.P. (1982) Volatile fatty acid and alcohol determination in digestive contents, silage juice, bacterial cultures and anaerobic fermentor contents. Sci. Aliments 2, 131-144

Jouany J.P. \& Senaud J. (1978) Utilisation du monensin dans la ration des ruminants. II. Effets sur les fermentations et la population microbienne du rumen. Ann. Zootech. 27, 6174

Jouany J.P. \& Thivend P. (1986) In vitro effects of avoparcin on protein degradability and rumen fermentation. Anim. Feed Sci. Technol. $15,215-229$

Muntifering R.B., Theurer B. \& Noon T.H. (1981) Effects of monensin on site and extent of whole corn digestion and bacterial protein synthesis in beef steers. J. Anim. Sci. 53, 15651573

Preston R.L., Pritchard R.H. \& Wolfrom G.W. (1985) Lysocellin effects on the gain, feed intake and efficiency of growing finishing cattle. J. Anim. Sci. 61 (suppl. 1), 493 (Abstr.)

Raab L., Cafantario B., Jilg T. \& Menke K.H. (1983) Rumen protein degradation and biosynthesis. I. A new method for determination of protein degradation in rumen fluid in vitro. Br. J. Nutr. 50, 569-582

Raun A.P., Cooley C.O., Rathmacher R.P., Richardson L.F. \& Potter E.L. (1974) Effect of different levels of monensin on feed efficiency, ruminal and carcass characteristics of cattle. Proc. West. Sect. Am. Soc. Anim. Sci. 25, 346347

Schelling G.T. (1984) Monensin mode of action in the rumen. J. Anim. Sci. 58, 1518-1527

Stanier G. \& Davies A. (1981) Effects of the antibiotic monensin and an inhibitor of methanogenesis on in vitro continuous rumen fermentations. Br. J. Nutr. 45, 567-578

Van Nevel C.J. \& Demeyer D.I. (1977) Effect of monensin on rumen metabolism in vitro. Appl. Environ. Microbiol. 34, 251-257

Van Nevel C.J. \& Demeyer D.I. (1979) Effect of monensin on some rumen fermentation parameters. Ann. Rech. Vét. 10, 338-340

Wardrope D.D., MacLeod N.S. \& Sloan J.R. (1983) Outbreak of monensin poisoning in cattle. Vet. Rec. 112, 560-561 